JFFI. 2018; 5(1) 246-252

www.jurnal.farmasi.umi.ac.id/index.php/fitofarmakaindonesia

\title{
EFEK SENYAWA BIOAKTIF KAYU MANIS Cinnamomum burmanii NEES EX.BL.) TERHADAP DIABETES MELITUS: KAJIAN PUSTAKA
}

\author{
Emilda $^{1}$ \\ Program Studi Pendidikan Biologi, FTMIPA, Universitas Indraprasta PGRI \\ 1emilda1430@gmail.com
}

\begin{abstract}
Diabetes Mellitus (DM) is a chronic disorder of carbohydrate metabolism (glucose) in the body and its prevalence is getting higher. Until 2015, 10 million cases of DM found in Indonesia and allegedly ever increasing. Type II DM is the most common types of DM in the world and its characterized by insulin resistance and $\beta$ cell damage. Due to the serious side effects caused when taking chemical antidabetes drugs, herbal medicine searches from natural materials continue to be done. Various spesieces of cinnamon plants have been studied and known to have antidiabetic activity. One of them is Cinnamomum burmanii which is found in Indonesia. Among the spesieces of cinnamon have the same health benefits including antidiabetes, antimicrobial, anti-fungal, antiviral, antioxidant, antitumor etc. Although the antidiabetic mechanism of cinnamon is still debated, it is thought that cinnamon affects several insulin signaling pathways, among others, in insulin receptors, glucose transporter 4 (GLUT 4), glucose transporter-1 (GLUT 1), peroxisome proliferator activator receptor (PPAR), $\alpha$ activity glucosidase etc. This activity is caused of the bioactive compounds it contains. The main compounds that have hypoglycemic activity are Methylhidroxy Calcone Polymer (MHCP), sinamaldehyde, and polymer pro-ayanine type-A polymers or proanthocyanidin.
\end{abstract}

Keywords: Diabetes melitus, $C$. burmanii, insulin resistence, $\beta$ cell damage, bioactive compound

\section{PENDAHULUAN}

Diabetes adalah kelompok penyakit metabolik kompleks yang ditandai oleh suatu keadaan hiperglikemia yaitu meningkatnya kadar gula darah melebihi kadar normal (Auroma et al., 2006). Menurut WHO, diabetes adalah ancaman yang meningkat bagi kesehatan masyarakat. Studi epidemeologi terhadap penderita diabetes menunjukkan dari 30 juta penduduk dunia yang menderita diabetes pada tahun 1985 meningkat menjadi 171 juta jiwa pada tahun 2000. Badan Kesehatan Dunia (WHO) memperkirakan pada tahun 2030 jumlah penderitanya akan melonjak menjadi 366 juta jiwa. Indonesia menempati peringkat ke-4 jumlah penderita diabetes terbanyak setelah India, Cina dan Amerika Serikat. Jumlahnya 8,4 juta pada tahun 2000 dan diperkirakan meningkat menjadi 21,3 juta pada tahun 2030 (Wild et al., 2004).

Diabetes melitus (DM) adalah suatu gangguan kronik metabolisme karbohidrat (glukosa) di dalam tubuh. Jumlah prevalensinya terus meningkat. Data Sample Registration Survey tahun 2014 menunjukkan bahwa DM merupakan penyebab kematian terbesar nomor 3 di Indonesia dengan persentase sebesar 6,7\%, setelah Stroke $(21,1 \%)$ dan penyakit Jantung Koroner (12,9\%) (Anonim, 2016). Apalagi penderita penyakit DM seringkali berkomplikasi kepada penyakit lainnya seperti serangan jantung, stroke, infeksi kaki yang berat dan berisiko amputasi, serta gagal ginjal stadium akhir. Estimasi terakhir International Diabetes Federation (IDF) terdapat 382 juta orang hidup dengan diabetes di dunia pada tahun 2013. Pada tahun 2035 jumlah tersebut diperkirakan akan meningkat menjadi 592 juta (Kemenkes, 2014). Sementara di Indonesia telah ditemukan 10 juta kasus diabetes pada tahun 2015 (IDF, 2017).

Diabetes tipe 2 merupakan tipe DM yang paling sering diderita masyarakat yang ditandai dengan resistensi insulin dan kerusakan sel $\beta$ (FDA, 2008). Banyak obat antidiabetes oral yang tersedia untuk pengobatan dan pengendalian DM Tipe 2, seperti agen sulfonylurea, biguanides (metformin), thiazolidinedione (TZD), inhibitor $\alpha$ - glukosidase, dan glucagon-like peptide-1 (GLP-1) inhibitor. Namun menurut Chattopadhyay (2009) dalam Fadillah (2014) obat-obat ini dapat menyebabkan efek samping yang serius, diantaranya hipoglikemia, toksisitas hati, peningkatan berat badan, physconia (pembesaran perut), dan asidosis laktat. Karena itu upaya untuk mencari obat-obat alternatif berbahan herbal terus dilakukan sebagai pengganti obat kimiawi. WHO merekomendasikan pula penggunaan obat tradisional termasuk herbal dalam pemeliharaan 
kesehatan masyarakat, pencegahan dan pengobatan penyakit, terutama untuk penyakit kronis, penyakit degeneratif dan kanker. Penggunaan obat tradisional secara umum dinilai lebih aman dari pada obat kimia modern. Hal ini disebabkan obat tradisional memiliki efek samping yang relatif lebih sedikit dari pada obat modern (Sari, 2006).

Penelitian-penelitian untuk mengeksplorasi zat aktif pada tumbuhan telah banyak dilakukan. Diantaranya telah ditemukan beberapa spesies tumbuhan yang memiliki aktifitas antidiabetes yang dapat menurunkan kadar gula darah atau memperbaiki sel $\beta$ pankreas. Govindappa M (2015) berhasil mengumpulkan sejumlah literatur dan me-list 419 spesies dari 133 famili tumbuhan yang memiliki aktifitas antidiabetes salah satunya kayu manis Cinnamomum zeylanicum. Sedangkan di Indonesia, spesies kayu manis yang ditemukan diantaranya Cinnamomum burmannii yang juga memiliki aktifitas hipoglikemia (Handayani dan Ahmad, 2006). Tujuan penulisan makalah ini ialah untuk mengetahui potensi pemanfaatan tumbuhan kayu manis Cinnamomum burmannii dalam mengatasi Diabetes melitus tipe II dan mengetahui kandungan senyawa bioaktif yang memiliki aktifitas antidiabetes.

\section{METODE PENELITIAN}

Metode penelitian yang digunakan adalah kajian kepustakaan dengan pendekatan deskriptif berdasarkan pustaka sekunder dari artikel-artikel penelitian. Penelusuran pustaka digali melalui situs google (www.google.co.id) dan google scholar (www.scholar.google.co.id) dengan kata kunci terkait seperti kayu manis, Cinnamomum burmannii ,diabetes, sinamaldehid (cynnamaldehida), proanthocyanidin, MHCP, dsb.

\section{PEMBAHASAN}

\section{Cinnamomi burmannii Blume (Kayu Manis)}

Tumbuhan kayu manis merupakan spesies dari genus Cinnamomum dengan famili Lauraceae, berupa tumbuhan berkayu yang umumnya dikenal sebagai rempah-rempah (Syarif, 2006 dalam Yulianis dkk, 2011). Tumbuhan ini tersebar di Asia Tenggara, Cina dan Australia. Terdapat sekitar 250 spesies yang termasuk genus Cinnamomum. Empat spesies yang utama adalah Cinnamomum zeylanicum (C. verum: 'True cinnamon', Sri Lanka atau Ceylon cinnamon), C. loureirii (Saigon atau Vietnamese cinnamon), $C$. burmanni (Korintje atau Indonesian cinnamon) dan Cinnamomum aromaticum (Cassia or Chinese cinnamon) (Bandara, 2011). Cinnamomum burmanii merupakan jenis kayu manis yang berasal dari Indonesia (Inna dkk, 2010). Dalam perdagangan Cinnamomum burmanii diberi nama Padang Kaneel atau cassiavera eks. Padang (Andianto, 2011).
Kulit kayu manis memiliki bau yang khas, banyak digunakan untuk berbagai keperluan, seperti penyedap rasa makanan atau kue (Abdurachman dan Hadjib, 2011). Kayumanis berbau wangi dan berasa manis sehingga dapat dijadikan bahan pembuat sirup dan rasa pedas sebagai penghangat tubuh. Kayu dari batang kayumanis dapat digunakan untuk berbagai keperluan seperti bahan bangunan, meubelair, dan kayu bakar (Ferry, 2013).

Al-Dhubiab (2012) menyebutkan komponen kimia terbesar pada kayumanis adalah alkohol sinamat, kumarin, asam sinamat, sinamaldehid, antosinin dan minyak atsiri dengan kandungan gula, protein, lemak sederhana, pektin dan lainnya. Ervina dkk (2016) menyatakan bahwa hasil ekstraksi kulit batang Cinnamomum burmanii mengandung senyawa antioksidan utama berupa polifenol (tanin, flavonoid) dan minyak atsiri golongan fenol. Kandungan utama minyak atsiri kayu manis adalah senyawa sinamaldehida dan eugenol. Wang et al (2009) dalam Hasan (2011) menyebutkan bahwa komponen mayor minyak atsiri yang terkandung pada daun Cinnamomum burmanii adalah transsinamaldehid $(60,17 \%)$, eugenol $(17,62 \%)$ dan kumarin $(13,39 \%)$. Identifikasi minyak atsiri batang $C$. burmannii dengan GC-MS dan LC-MS menemukan adanya senyawa utama sinamaldehid dan beberapa polifenol terutama proanthocyanidin dan epi-catechin (Shan B, 2007). Chen et al (2014) menemukan diantara 4 spesies cinnamon yaitu $C$. burmannii, $C$. verum, $C$. aromaticum, dan $C$. Loureiroi semua ekstraknya memiliki manfaat kesehatan yang sama. Yang membedakannya $C$. burmannii memiliki rasa yang tidak terlalu pahit seperti $C$. cassia and $C$. loureiroi. Tingkat kandungan senyawa aktif pada tumbuhan bisa berubah tergantung metode yang digunakan dalam proses ekstraksinya (Duguoa et al, 2007).

Bandara et.al (2011) menyebutkan bahwa cinnamon memiliki kemampuan antimikroba, antifungi, antivirus, antioksidan, antitumor, penurun tekanan darah, kolesterol dan memiliki senyawa rendah lemak. Senyawa eugenol dan sinamaldehid memiliki potensi sebagai antibakteri dan antibiofilm (Niu C dan Gilbert ES, 2004). Penelitian Shan B et al (2007) membuktikan kemampuan ekstrak kulit batang cinnamon melawan 5 jenis bakteri patogen yaitu Bacillus cereus, Listeria monocytogenes, Staphylococcus aureus, Escherichia coli, dan Salmonella anatum. Nisa dan Triastuti (2014) melaporkan sifat antibakteri ekstrak kayu manis terhadap E. coli dan S. aureus. Sedangkan penelitian Daker dkk (2013) menunjukkan ekstrak metanol kulit batang Cinnamomum burmannii Blume dengan senyawa utamanya trans-cinnamaldehyde (TCA) yang memiliki kemampuan menghambat proliferasi human NPC cell. 
Mekanisme aktifitas antidiabetes dari cinnamon masih diperdebatkan, namun diduga aktifitas cinnamon berpebgaruh pada beberapa jalur sinyal insulin yaitu pada reseptor insulin, glucose transporter 4 (GLUT 4), glucose transporter-1 (GLUT-1), glucagon-like peptide-1 (GLP-1), Peroxisomeproliferator activator receptor (PPAR), aktifitas $\alpha$ glucosidase, pengaruh pada glukoneogenesis, dan pengosongan lambung (Medagama, 2015).

Pada gambar dibawah ditampilkan mekanisme molekul cinnamon mempengaruhi aktifitas hipoglikemia.
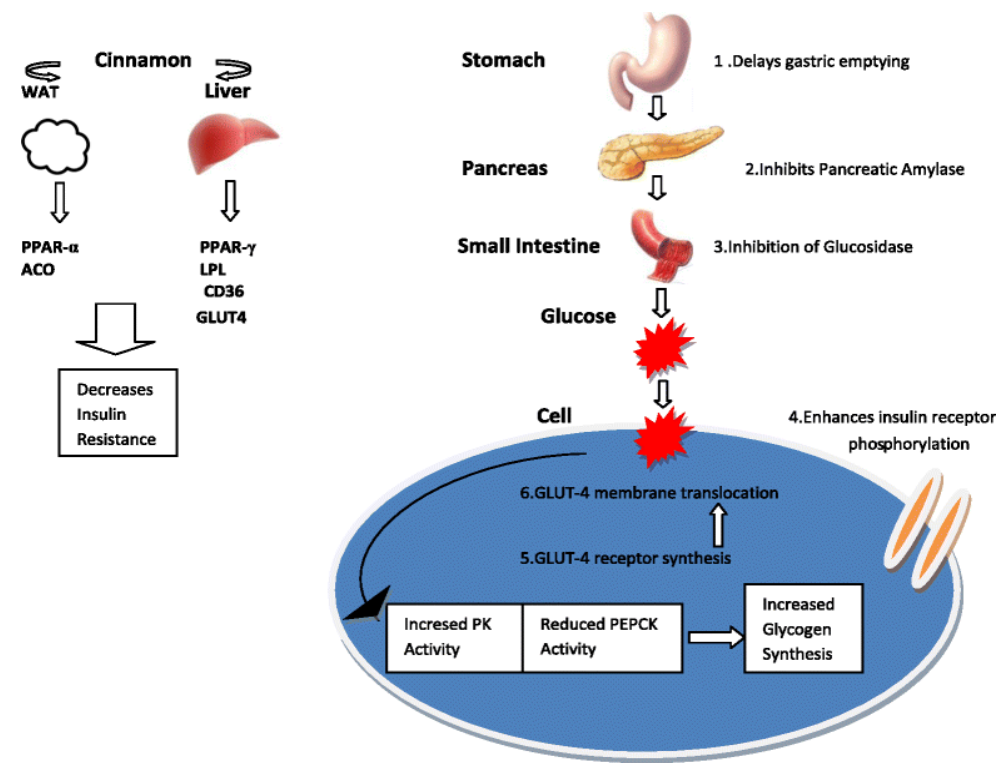

Gambar 1. Mekanisme molekul cinnamon mendesak aktifitas hipoglikemia (Medagama, 2015)

(Keterangan: PK: Pyruvate Kinase, PEPCK: Phosphoenol Carboxy Kinase, PPAR-gamma: Peroxisome Proloferator Activated-Receptor gamma, WAT: White Adipose Tissue, ACO: Acyl-CoA Oxidase, GLUT-4: Glucose transporting protein 4, LPL: Lipoprotein lipase, CD36:Fatty Acid Transporter)

\section{Diabetes Melitus Tipe II}

Diabetes melitus adalah penyakit kronis serius yang terjadi baik saat pankreas tidak menghasilkan insulin yang cukup atau bila tubuh tidak dapat secara efektif menggunakan insulin yang dihasilkannya (WHO, 2016). Insufisiensi fungsi insulin dapat disebabkan oleh gangguan atau defisiensi produksi insulin oleh sel-sel $\beta$ Langerhans kelenjar pankreas, atau disebabkan oleh kurang responsifnya sel-sel tubuh terhadap insulin (WHO, 1999 dalam Depkes 2005).

Berdasarkan penyebab ini, DM diklasifikasikan sebagai berikut:

a. Tipe I (disebut juga diabetes insulin-dependent, juvenile or childhood-onset) yang dicirikan dengan kekurangan produksi insulin oleh tubuh (WHO, 2016). Penyebabnya belum diketahui dan tidak bisa dicegah. Gejala yang terlihat adalah banyak menghasilkan urin dan sering haus, sering lapar, penurunan berat badan, penglihatan terganggu dan cepat lelah. Gangguan produksi insulin pada DM tipe 1 umumnya terjadi i kerudiseakan sel-sel $\beta$ Langerhans karena reaksi otoimun. Namun ada pula yang disebabkan oleh virus, seperti virus Cocksakie, Rubella, CMVirus, Herpes, dan lain sebagainya (Depkes, 2005)

b. Tipe II (disebut juga diabetes non-insulindependent or adult-onset) disebabkan penggunaan insulin yang tidak efektif oleh tubuh. Gejala mirip dengan tipe I tetapi seringkali gejala ini tidak terlihat. Akibatnya, penyakit ini tidak terdiagnosis selama beberapa tahun, sampai komplikasi sudah terjadi (WHO, 2016). Penyebab DM tipe 2 multifaktor yang belum sepenuhnya terungkap dengan jelas. Faktor genetik dan pengaruh lingkungan cukup besar dalam menyebabkan terjadinya DM tipe 2, antara lain obesitas, diet tinggi lemak dan rendah serat, serta kurang gerak badan (Depkes, 2005).

Pada penderita DM Tipe 2, awalnya disebabkan sel-sel sasaran insulin tidak mampu merespon insulin secara normal atau disebut resistensi insulin. Resistensi insulin secara dramatis mengganggu ambilan glukosa di jaringan perifer dan mengakibatkan produksi glukosa yang berlebihan oleh hati. Hal ini berpengaruh pada terjadinya hiperglikemia pada penderita diabetes 
(Olefsky dalam Tjandrawinata, 2016). Disamping itu dapat juga timbul gangguan sekresi insulin dan produksi glukosa hepatik yang berlebihan. Namun defisiensi fungsi insulin pada penderita DM Tipe 2 hanya bersifat relatif, karena tidak terjadi pengrusakan sel-sel $\beta$ Langerhans secara otoimun. Penelitian mutakhir menunjukkan bahwa pada penderita DM Tipe 2 umumnya ditemukan kedua faktor tersebut, yaitu resistensi insulin dan defisiensi insulin (Depkes, 2005).

\section{c. Diabetes Mellitus Gestasional} (GDM=Gestational Diabetes Mellitus) adalah keadaan diabetes atau intoleransi glukosa yang timbul selama masa kehamilan, dan biasanya berlangsung hanya sementara atau temporer. Sekitar 4-5\% wanita hamil diketahui menderita $G D M$, dan umumnya terdeteksi pada atau setelah trimester kedua (Depkes, 2005).

d. Diabetes Melitus Tipe Lain yaitu DM disebabkan kelainan genetik, penyakit pankreas, obat, infeksi, antibodi, sindrom penyakit lain. Diabetes tipe lain dapat juga disebabkan defek genetik fungsi insulin, defek genetik kerja insulin, penyakit eksokrin pankreas, endokrinopati, karena obat atau zat kimia (Sutjahjo dkk, 2006 dalam Ambarwati, 2012).

Pengobatan DM dapat dilakukan dengan pemberian insulin, obat hipoglikemik oral baik obat sintetis maupun herbal (Wadkar et al., 2007 dalam Anggriawan dkk, 2015). Pada DM Tipe II penatalaksanaan resistensi insulin selain untuk mencegah timbulnya diabetes melitus, juga akan mencegah komplikasi penyakit kardiovaskuler (Merentek, 2006).

\section{Aktifitas Antidiabetes Ekstrak Cinnamomum burmannii Blume}

Sejumlah penelitian tentang pemanfaatan kayu manis khususnya jenis Cinnamomum burmannii Blume menunjukkan adanya aktifitas antidiabetes yang berbeda-beda. Diantaranya penelitian Tjahjani dkk (2014) membuktikan pemberian ekstrak etanol kayu manis dosis $20,8 \mathrm{mg}$ kepada mencit mampu menurunkan glukosa darah. Ekstrak kayu manis dosis 20,8 mg sama efektifnya dengan glibenklamid dalam menurunkan glukosa darah. Begitupula Alusinsing dkk (2014) juga membuktikan terjadinya penurunan kadar gula darah pada mencit setelah diberi ekstrak etanol kulit kayu manis. Penelitian Kusumaningtyas dkk (2014) dengan memberikan seduhan bubuk kayu manis pada dosis $0,73 \mathrm{mg} / \mathrm{g}$ bb mampu memperbaiki struktur pankreas mencit jantan strain Balb-C setelah dipapar dengan aloksan. Selain pada kulit batang, aktifitas antidiabetes juga didapatkan dari ekstrak daun kayu manis. Penelitian Kondoy dkk (2013) menemukan bahwa ekstrak etanol daun kayu manis dapat menurunkan kadar gula darah pada tikus putih jantan galur wistar yang diinduksi sukrosa.

Bernardo et al (2015) melaporkan bahwa teh cinnamon dari bubuk kulit batang bermanfaat untuk mengendalikan metabolisme glukosa pada orang dewasa nondiabetes selama periode postprandial. Analisis kimia menunjukkan bahwa teh cinnamon memiliki kapasitas antioksidan yang tinggi yang diduga karena kandungan polifenolnya. Hasil penelitian Anggriawan dkk (2015) bahwa ekstrak air dan etanol C.burmannii mampu menghambat aktivitas enzim $\alpha$-Glukosidase. Aktivitas penghambatan tertinggi terhadap enzim $\alpha$ Glukosidase adalah dari ekstrak etanol 30\% C.burmannii konsentrasi $1.5 \%$ dan ekstrak air C.burmannii konsentrasi $1.5 \%$ dengan daya inhibisi berturut-turut adalah $94.88 \%$ dan $94.51 \%$. Ekstrak tersebut memiliki daya penghambatan tidak berbeda nyata dengan kontrol positif yaitu Glucobay (Akarbosa) 1\% sebesar 100.03\%.

Meskipun belum ada bukti yang pasti, namun diduga kuat sejumlah senyawa bioaktif yang memiliki aktifitas antidiabetes pada C.burmannii diantaranya Methylhidroxy Calcone Polymer (MHCP) (Dougua et al, 2007), sinamaldehid (Ngadiwiyana dkk, 2011), polimer procyanidin type-A polymers (Medagama, 2015). Sedangkan senyawa lain seperti asam sinamat, sinamid, alkohol sinamat, eugenol dan 2-metoksi sinamaldehid menunjukkan aktifitas yang kecil atau tidak ada (Medagama, 2015)

\section{Sinamaldehid}

Sinamaldehid adalah salah satu jenis komponen fenilpropanoid yang banyak terdapat dalam Cinnamomum sp. Pada Cinnamomum zeylanicum terdapat kandungan $75 \%$ sinamaldehid (Fazilah et al (2006) dalam Yusof (2012). Penelitian Wardatun dkk (2017) menemukan dari 100 gr kulit kayu manis C.burmannii kering yang diekstraksi dengan teknik maserasi etanol $96 \%$ diperoleh sinamaldehid sebanyak $124.14 \pm 1.17 \mathrm{mg} / \mathrm{g}$.

Joshi et al., 2009 dalam Yusof (2012) menyebutkan sinamaldehid memiliki aktifitas biologi sebagai antioksidan, antivirus, antifungi and antibakteri. Ngadiwiyana dkk (2011) telah membuktikan bahwa senyawa sinamaldehid hasil isolasi dari minyak kayu manis mempunyai nilai $\mathrm{IC}_{50}$ sebesar 27,96 ppm terhadap enzim $\alpha$-glukosidase sehingga sangat potensial sebagai senyawa penghambat aktivitas enzim $\alpha$-glukosidase. Sinamaldehid secara signifikan menurunkan tingkat gula puasa, meningkatkan sensitifitas insulin dan memperbaiki morfologi islet serta fungsi pada tikus $\mathrm{db} / \mathrm{db}$ (Guo et al, 2017). 
Zhu R et al (2017) menyatakan bahwa dari berbagai hasil penelitian terbukti sinamaldehid memperlihatkan efek penurunan gula pada hewan uji melalui peningkatan pengeluaran gula dan perbaikan sensitifitas insulin pada jaringan adiposa dan jaringan otot, meningkatkan sintesis glikogen di hati, memperbaiki disfungsi islet pankreas, memperlambat waktu pengosongan lambung, memperbaiki gangguan ginjal karena diabetes dan kerusakan otak.

\section{Methylhidroxy Calcone Polymer (MHCP)}

Senyawa Methylhidroxy Calcone Polymer (MHCP) adalah flavonoid yang memiliki efek mirip insulin. MHCP pada kayu manis mempunyai kerja seperti insulin yaitu mengaktivasi sintesis glikogen, meningkatkan pengambilan glukosa, mengaktivasi insulin reseptor kinase dan menghambat defosforilasi reseptor insulin (Tjahjani, 2014).

Kerja MHCP antara lain ialah dengan meningkatkan konsentrasi IRS-1, suatu reseptor insulin yang akan mengaktifkan jalur PI-3K. Pengaktifan jalur PI-3K ini akan menyebabkan peningkatan sintesis lipid, protein, glikogen oleh glikogen sintase, serta menstimulasi proliferasi selsel. Mekanisme ini bertanggung jawab dalam proses distribusi glukosa ke dalam sel. PI-3K selanjutnya akan menyebabkan GLUT-4 yang terdapat dalam sitosol bergerak menuju membran sel sehingga glukosa dapat masuk ke dalam sel dan menuju ke mitokondria untuk diubah menjadi ATP. Kerja MHCP lainnya yaitu dengan menghambat enzim GSK-3b yang berfungsi untuk menghambat glycogen synthase dan menghambat PTP-1 yang bertugas dalam proses defosforilasi reseptor insulin (Hlebowicz et al, 2007 dalam Gunawan dan Suhendra (2013).

MHCP menjadikan sel lemak lebih responsif terhadap insulin dengan mengaktifkan enzim yang menyebabkan insulin dapat berikatan dengan sel (insulin-receptorkinase) dan menginhibisi enzim yang menghalangi proses ini (insulin-receptorphosphatase) yang mendorong proses fosforilasi maksimal reseptor insulin yang berhubungan dengan meningkatnya sensitifitas insulin (Safdar et al, 2004). Aktifitas proanthocyanidin dan MHCP pada bubuk kayu manis juga dapat menurunkan kadar kolesterol (Soemardini dkk, 2011 dalam Vanessa dkk, 2014).

\section{Proanthocyanidin}

Proanthocyanidin adalah sejenis polifenol yang banyak ditemukan pada tumbuhan. Peneliti di Perancis telah menemukan suatu senyawa bioflavonoid yang tidak berwarna pada biji anggur merah yang ternyata mengandung proanthocyanidins sebanyak 95\%. Dalam penelitiannya, zat tersebut diberi nama Oligomer Proanthocyanidin Complex (OPC) (Liers, 1993 dalam Djoka dkk, 2012).
Bernardo (2015) menyebutkan bahwa dalam kajian Peng dan rekannya menemukan bahwa proanthocyanidin dari ekstrak cair cinnamon dapat mencegah pembentukan advanced glycation-end product (AGE). Keberadaan AGE mengawali produksi gula darah tinggi yang berkaitan dengan produksi reactive oxygen species (ROS).

Aron (2007) dalam Djoka dkk (2012) OPC dapat berperan sebagai antioksidan melalui beberapa mekanisme yaitu scavenging free radicals, chealation of transition metals, serta inhibitor enzim (Aron, 2007 dalam Djoka dkk, 2012). Flavonoid juga diketahui sebagai antioksidan karena mampu menurunkan stress oksidatif. Hal ini dapat menimbulkan efek protektif terhadap sel beta pankreas dan meningkatkan sensitivitas insulin (Kaneto et al, 1999 dalam Djoka dkk, 2012).

\section{KESIMPULAN}

Berdasarkan paparan diatas disimpulkan bahwa tumbuhan kayu manis jenis Cinnamomum burmannii Blume yang banyak ditemukan di Indonesia memiliki aktifitas antidiabetes. Ekstrak kulit batang atau daunnya berpotensi dimanfaatkan untuk mengatasi DM tipe II yang ditandai dengan resistensi insulin dan defisiensi insulin. Aktifitas antidiabetes yang ditunjukkannya berbeda-beda antara lain pada penurunan kadar gula darah, penghambatan terhadap aktifitas enzim $\alpha$ Glukosidase dan pengendalian metabolisme glukosa pada orang dewasa nondiabetes selama periode postprandial. Meskipun masih diperdebatkan, diduga kemampuan antidiabetes pada kayu manis disebabkan kandungan senyawa bioaktif yang terkandung didalamnya. Senyawa utama antidiabetesnya antara lain Methylhidroxy Calcone Polymer (MHCP), sinamaldehid, dan polimer procyanidin type-A polymers atau proanthocyanidin.

\section{DAFTAR PUSTAKA}

Abdurachman dan Nurwati H. 2011. Sifat Papan Partikel dari Kayu Kulit Manis (Cinnamomum burmanii BL). Jurnal Penelitian Hasil Hutan Vol. 29 No. 2, Juni 2011: 128-141

Al-Dhubiab, B. E. (2012). Pharmaceutical Applications and Phytochemical Profile of Cinnamomum burmannii. Pharmacognosy Reviews, 6(12), 125-131.

Alusinsing G dkk. 2014. Uji Efektivitas Kulit Batang Kayu Manis (Cinnamomum Burmanii) Terhadap Penurunan Kadar Gula Darah Tikus Putih Jantan Galur Wistar (Rattus Norvegicus) yang Diinduksi Sukrosa. Pharmacon Jurnal Ilmiah Farmasi - Unsrat Vol. 3 No. 3. 
Ambarwati WN, 2012. Konseling Pencegahan dan Penatalaksanaan Penderita Diabetes Mellitus. Prosiding Seminar Nasional Keperawatan. Program Studi Keperawatan Fakultas Ilmu Kesehatan. Universitas Muhammadiyah Surakarta.

Andianto. 2011. Pohon Berkhasiat Obat dan Keberadaannya. Pusat Penelitian dan Pengembangan Keteknikan Kehutanan dan Pengolahan Hasil Hutan. Departemen Kehutanan RI.

Anggriawan MB dkk. 2015. Potensi Ekstrak Air dan Etanol Kulit Batang Kayu Manis Padang (Cinnamomum Burmanii) Terhadap Aktivitas Enzim A-Glukosidase. Jurnal Kedokteran Yarsi 23 (2) : 091-102 (2015)

Anonim. 2016. Menkes: Mari Kita Cegah Diabetes dengan Cerdik. Biro Komunikasi dan Pelayanan Masyarakat, Kementerian Kesehatan RI. Diakses 21-11-2017.

Bandara T et al. 2011. Bioactivity of Cinnamon with Special Emphasis on Diabetes Mellitus: A review. International Journal of Food Sciences and Nutrition, 2011; Early Online: 1-7

Bernardo MA et al (2015). Research Article: Effect of Cinnamon Tea on Postprandial Glucose Concentration. Journal of Diabetes Research. Volume 2015, 6 pages

Chen P et al (2014). Differentiation of the Four Major Species of Cinnamons ( $C$. burmannii, $C$. verum, $C$. cassia, and $C$. loureiroi) Using a Flow Injection Mass Spectrometric (FIMS) Fingerprinting Method. J. Agric Food Chem 2014 Mar 26; 62(12): 2516-2521.

Daker $\mathrm{M}$ et al. 2013. Inhibitory Effects of Cinnamomum Burmannii Blume Stem Bark Extract and Trans-Cinnamaldehyde on Nasopharyngeal Carcinoma Cells; Synergism With Cisplatin. Experimental and Therapeutic Medicine 2013 Jun; 5(6): 17011709. Spandidos Publications

Departemen Kesehatan RI. 2005. Pharmaceutical Care Untuk Penyakit Diabetes Mellitus. Direktorat Bina Farmasi Komunitas Dan Klinik, Direktorat Jenderal Bina Kefarmasian Dan Alat Kesehatan.

Djoka MCY dkk. 2012. Pengaruh Ekstrak Biji Anggur Merah (Vitis Vinifera) Terhadap Penurunan Kadar Glukosa Darah Tikus Putih Strain Wistar Model Diabetikum. Saintika Medika Volume 8 No 1 Juni 2012

Duguoa JJ et al. 2007. From Type 2 Diabetes to Antioxidant Activity: A Systematic Review of The Safety and Efficacy of Common and Casia Cinnamon Bark. Canadian Journal
Physiologi Pharmacology Vol 85, 2007. P: 837-847

Ervina M dkk. 2016. Comparison of In Vitro Antioxidant Activity of Infusion, Extract and Fractions of Indonesian Cinnamon (Cinnamomum Burmannii) Bark. International Food Research Journal 23(3): 1346-1350.

Fadillah RU. 2014. Antidiabetic Effect of Morinda Citrifolia L. As A Treatment of Diabetes Mellitus. Jurnal Majority Volume 3 Nomor 7.

Ferry Y. 2013. Prospek Pengembangan Kayu Manis (Cinnamomum Burmanii L) di Indonesia. SIRINOV, Vol 1, No 1, April 2013 ( Hal : 11 $-20)$

Food and Drug Administration. 2008. Guidance for Industry Diabetes Mellitus - Evaluating Cardiovascular Risk in New Antidiabetic Therapies to Treat Type 2 Diabetes. U.S. Department of Health and Human Services Food and Drug Administration Center for Drug Evaluation and Research (CDER)

Gunawan CO dan Adrian S. 2013. Efek Kayu Manis (Cinnamomum burmannii) Terhadap Kadar Glukosa Darah Postprandial. Online. http://repository.maranatha.edu/12183/10/1 010066_Journal.pdf

Govindappa M. 2015. A Review on Role of Plant(s) Extracts and its Phytochemicals for the Management of Diabetes. Journal Diabetes Metab 2015, 6:7

Guo X et al . 2017. Effect of Cinnamaldehyde on Glucose Metabolism and Vessel Function. Medical Science Monitor. 2017; 23: 38443853.

Handayani FW dan Ahmad M. 2006. Beberapa Tumbuhan Di Indonesia Berpotensi Sebagai Alternatif Obat Antidiabetes. Jurnal Farmaka Volume 4 No 4.

Hasan NF. 2011. Chemical Composition and Biological Activity of Essential Oil From Cinnamomum spp. and Litsea spp. Dissertation. Faculty of Resource Science and Technology. Universiti Malaysia Sarawak

Inna M dkk. 2010. Potential Use of Cinnamomum burmanii Essential Oil-based Chewing Gum as Oral Antibiofilm Agent: Literature Review. Journal of Dentistry Indonesia 2010, Vol. 17, No. 3, 80-86

International Diabetes Federation. 2017. IDF Western Pacific members: Indonesia. https://www.idf.org/our-network/regions- 
members/western-pacific/members/104-

indonesia.html. Diakses 17-11-2017

Kementerian Kesehatan RI, 2014. Situasi dan Analisis

Diabetes Waspada Diabetes Eat Well Live

Well. Infodatin. Pusat Data dan Informasi

Kementerian Kesehatan RI. Diakses 9-112017

Kondoy S dkk. 2013. Potensi Ekstrak Etanol Daun Kayu Manis (Cinnamomum Burmanii) Terhadap Penurunan Kadar Glukosa Darah Dari Tikus Putih Jantan (Rattus Norvegicus) Yang Di Induksi Sukrosa. Pharmacon Jurnal Ilmiah Farmasi - UNSRAT Vol. 2 No. 03

Kusumaningtyas ID dkk. 2014. Pengaruh Seduhan Kayu Manis (Cinnamomum burmanii) Terhadap Struktur Pankreas Mencit (Mus musculus) Strain Balb-C Diabetik. Jurnal Ilmu Dasar, Vol.15 No.2, Juli 2014: 69-73

Medagama AB. 2015. The glycaemic outcomes of Cinnamon, a review of the experimental evidence and clinical trials. Jurnal Online. Nutrition Journal 2015 14:108

Merentek E. 2006. Tinjauan Kepustakaan: Resistensi Insulin Pada Diabetes Melitus Tipe 2. Cermin Dunia Kedokteran No. 150, 2006

Ngadiwiyana dkk. 2011. Potensi Sinamaldehid Hasil Isolasi Minyak Kayu Manis Sebagai Senyawa Antidiabetes. Majalah Farmasi Indonesia, 22 (1), 9 - 14.

Nisa LC dan Triastuti R. 2014. Aktivitas Antibakteri Kulit Kayu Manis (Cinnamomum Burmanni) Dengan Cara Ekstraksi Yang Berbeda Terhadap Escherichia Coli Dan Staphylococcus Aureus. Naskah Publikasi. Diakses 30-11-2017

Niu C dan Gilbert ES, 2004. Colorimetric Method for Identifying Plant Essential Oil Components That Affect Biofilm Formation and Structure. Applied Environment Microbiology. December 2004 vol. 70 no. 126951-6956

Safdar M et al, 2004. Effect of various doses of cinnamon on blood glucose in diabetic individuals. Pak J Nutr. 2004;3.

Shan B et al. 2007. Antibacterial Properties and Major Bioactive Components of Cinnamon Stick (Cinnamomum Burmannii): Activity Against Foodborne Pathogenic Bacteria. Journal Agriculture Food Chemistry. $2007 \mathrm{Jul}$ 11:55(14):5484-90.

Sari LORK, 2006. Pemanfaatan Obat Tradisional Dengan Pertimbangan Manfaat Dan
Keamanannya. Majalah Ilmu Kefarmasian, Vol. III, No.1, April 2006, $01-07$

Tjandrawinata RR. 2016. Patogenesis Diabetes Tipe 2: Resistensi Insulin Dan Defisiensi Insulin. A Working Review Paper. Dexa Laboratories of Biomolecular Sciences (DLBS) Dexa Medica Group. Diakses 24-11-2017

Tjahjani S dkk. 2014. Efek Ekstrak Etanol Kayu Manis (Cinnamomum burmannii) Terhadap Penurunan Kadar Glukosa Darah. Online. http://repository.maranatha.edu/12623/10/11 10110_Journal.pdf

Vanessa R dkk. 2014. Pemanfaatan Minuman Serbuk Instan Kayu Manis (Cinnamomum burmanii Bi.) Untuk Menurunkan Kadar Kolesterol Total Darah Tikus Putih (Rattus Norvegicus). Online. http://ejournal.uajy.ac.id/5385/1/JURNAL.pdf

Wardatun S dkk. 2017. Study Effect Type of Extraction Method And Type of Solvent To Cinnamaldehyde and Trans-Cinnamic Acid Dry Extract Cinnamon (Cinnamomum burmanii [Nees \& T, Nees]Blume) . J Young Pharm, 2017;9(1) Suppl: s49-s51

World Health Organization. 2016. Global Report on Diabetes. WHO Library Cataloguing-inPublication Data

Yulianis dkk. 2011. Penetapan Kadar Kumarin dari Kulit Manis (Cinnamomum burmanii B1.) dengan Metoda Kromatografi Gas. Jurnal Sains dan Teknologi Farmasi, Vol. 16, No.2, 2011, halaman 203-208

Yusof NS. 2012. Phytochemical Studies And Biological Activity Of Cinnamomum Microphyllum. Thesis. Faculty of Resource Science and Technology. Universiti Malaysia Sarawak

Zhu R et al. 2017. Review Cinnamaldehyde In Diabetes: A Review of Pharmacology, Pharmacokinetics and Safety. Jurnal Online. Pharmacological Research Volume 122, Pages 78-89 